\title{
Groundwater Management Under Global Change: Sustaining Biodiversity, Energy and Food Supplies
}

\author{
Jamie Pittock, Karen Hussey, and Andrew Stone
}

\begin{abstract}
This chapter grapples with the challenge of simultaneously sustaining biodiversity, energy and food supplies in conjunction with efforts to mitigate and adapt to climate change. Managing groundwater supplies sustainably is critical to that challenge, and the chapter assesses the positive synergies and perverse impacts for sustaining groundwater resources from both climate change mitigation and adaptation policies. The chapter finds that the pressures on groundwater resources will likely increase in the future, with the location, scale and magnitude of groundwater use shifting in response to other pressures. For example, changing energy policies are resulting in rapid deployment of thirsty technologies. Similarly, climate change adaption will increasingly rely on the water storage capacity of aquifers, yet many adaptation measures may also increase groundwater use. For better groundwater management under global change pressures we recommend a focus on complementary measures to: integrate information, deploy appropriate new technologies, apply market-based incentives and improve cross-sectoral governance. The key challenge for proponents of sustaining groundwater resources is to engage stakeholders and decisionmakers outside the water sector in governance institutions.
\end{abstract}

J. Pittock $(\square) \cdot$ K. Hussey

Fenner School of Environment and Society, The Australian National University, Canberra, Australia

e-mail: Jamie.pittock@anu.edu.au

A. Stone

American Ground Water Trust, Concord, USA

(C) The Author(s) 2016

A.J. Jakeman et al. (eds.), Integrated Groundwater Management,

DOI 10.1007/978-3-319-23576-9_4 


\subsection{Introduction}

Increased demand for freshwater wrought by an increasing population, wealth and consumption of thirstier products will be exacerbated by climate change. While the direct impacts of climate change on groundwater recharge is uncertain, it is certain that climate change mitigation and adaptation policies will change. In some cases, shifts in policy will exacerbate the challenges associated with groundwater use and management. This chapter extends the detailed technical and governance information on groundwater in the following chapters (see especially Part II) to consider the implications of these significant and urgent global changes for the management of groundwater, and to suggest approaches to sustaining biodiversity while maintaining energy and food supplies under a changing climate.

In the next section, the little-appreciated synergies between climate mitigation policies and groundwater resources are explored. Energy demand management measures have positive synergies in reducing consumption of water, but the impacts of new energy technologies on groundwater are mixed: some increase and others decrease water consumption, the location of water use will change, and governments are being challenged to adequately regulate the rapid uptake of these new industries. Carbon sequestration in the landscape will have neutral impacts at best, but is more likely to have negative impacts on groundwater resources. In particular, the beguiling political appeal of tree planting and soil carbon heightens the risk that perverse impacts on groundwater will be poorly managed. Similarly, groundwater plays a significant role in climate change adaptation for water supply, food production and biodiversity conservation, due in part to the longer-term processes of recharge and storage that buffers aquifers from the short-term climatic and surface hydrology variability. These roles require more active and sustainable management of aquifers than has been achieved to date around the world.

The final section of this chapter considers options for meeting the challenge of more effectively managing groundwater to offset negative impacts of these global changes. The magnitude and location of tensions between groundwater, food and energy vary considerably from country to country and aquifer to aquifer. The drivers of groundwater depletion and demand for use vary at the local, regional and global scales. Thus, analysis of future impacts and associated solutions is complex and a range of disciplines is needed to understand how to manage the inter-linkages between the numerous drivers of groundwater use, from technology assessment through to the international political economy. It is with this multidisciplinary framing that we begin to step through issues and options for managing groundwater more sustainably in a growing world and under a changing climate. 


\subsection{Implications of Climate Change for Groundwater}

\subsubsection{Direct Impacts from Climate Change}

Modified weather patterns resulting from global climate change will affect rates of groundwater recharge differently in different parts of the world as outlined in Chap. 5. Precipitation will likely change in intensity, duration and frequency. In many areas, groundwater recharge may increase, as a result of increased precipitation totals, from more frequent large floods, or as a result of melting of permafrost (IPCC 2007a). In other regions, reduced precipitation and higher evapotranspiration are likely to decrease aquifer recharge. A number of these counter-veiling factors may occur in the same region making the outcome uncertain. For example, in the Murray-Darling Basin in south eastern Australia, while surface water availability may decline, under a changing climate, the infrequent but large floods may significantly contribute to aquifer recharge (CSIRO 2008; Hirabayashi et al. 2013).

Changes in vegetation land cover affecting runoff and recharge will occur due to climatic change and will exacerbate human impacts such as deforestation. Shifting of traditional climate and vegetation zones will result in alterations in the species composition of forests, rising snow lines, and more frequent wildfires. The latter may impact flood frequency and intensity, erosion, and dam siltation. The resultant effects on groundwater recharge will in turn affect rates and volumes of groundwater discharge to springs, stream base-flow and the availability of groundwater for pumping (Bates et al. 2008). The challenge for groundwater managers is to develop strategies that account for uncertainty, in a manner that can provide satisfactory outcomes for water use under a range of climate conditions (WWDR 2012). Example strategies range from conservative allocation limits to the use of threshold or contingency policies that trigger alternative management arrangements according to water availability conditions, and augmentation of storage through managed aquifer recharge (Chaps. 17 and 18).

In addition to the need for robust management that accounts for uncertainty, questions arise as to how climate change mitigation policies may avoid unsustainable impacts on groundwater, or how they may even benefit the resource.

\subsubsection{Climate Change Mitigation Policies}

Climate change mitigation policies typically fall into three categories: demand side, supply side and sequestration or storage focused strategies (IPCC 2007b). Demand side policies aim to reduce energy consumption and thus emissions of greenhouse gasses. Supply side policies shift the generation of energy away from fossil fuels to low-carbon sources. Sequestration approaches encourage the use of natural storage of greenhouse gasses in the landscape. Reducing greenhouse gas concentrations in the atmosphere to achieve an oft-expressed desire to limit global warming below $2{ }^{\circ} \mathrm{C}$ will require all of these approaches (Rogelj et al. 2013), and they all have implications for groundwater storage inventories. However, the groundwater 
consumption and storage implications of different mitigation measures vary considerably. Wallis et al. (2014) reviewed the water use implications of 74 mitigation measures for Australia and found that positive synergies existed between conserving energy and conserving water in a variety of demand management interventions. However, they also found that neutral and negative outcomes for water consumption are evident for a range of emerging low-emission energy technologies, and similarly, that very negative consequences could be expected from carbon sequestration measures. These findings are elaborated on below, specifically in relation to groundwater.

\subsubsection{New and Emerging Energy Technologies}

The quest for low-emission energy sources is driving rapid policy change as regulations, carbon pricing and technological innovation combine to favour rapid deployment of more modern energy technologies. The focus on reducing greenhouse gas emissions has meant that the impacts on water resources have received very little attention. Booming industries, such as biofuels in the United States (US) and unconventional gas production globally, have developed in advance of efforts by government regulators to require application of better practices, including sustaining groundwater resources (Hussey and Pittock 2012). In Australia, new financial incentives for low-emission energy sources have been adopted without fully considering how well carbon, energy and water markets are harmonised to avoid externalities (Pittock et al. 2013). To inform this analysis a number of cases with risks to groundwater from expansion of emerging energy technologies are considered, including biofuels, (hot-rock) geothermal, unconventional gas, solar thermal and ground-source heating and cooling systems.

\section{Biofuels}

First generation biofuels use crops that are frequently irrigated from groundwater like corn, sugar cane and beet to produce ethanol and oil palm and soy to generate biodiesel. Water consumption to grow these feed stocks means that these alternative fuels have water footprints several orders of magnitude higher than most conventional and renewable energy systems (Gerbens-Leenes et al. 2008). Yet, there has been a rapid expansion of these industries driven by subsidies and renewable fuel quotas in jurisdictions including Australia, Brazil, the European Union and the US (Pittock 2011).

There are reports that up to 281 of irrigation water are needed to produce enough soybeans to propel an average vehicle $1 \mathrm{~km}$. In comparison, water needs for gasoline (petrol) are merely $0.33 \mathrm{l}$ of water for each vehicle $1 \mathrm{~km}$ (King and Webber 2008). As is true for the agricultural sector generally, limiting the impacts on groundwater resource use by biofuels requires good governance, including allocation systems that cap extraction at sustainable levels and maximise social and economic benefits from the water consumed. However, the political power of biofuel industries in some countries may compel policies that encourage non-sustainable use and allocation (Notaras 2011). For example, the 2007 Energy Independence and Security Act in the US mandates an increase in annual biofuels 
production, requiring an additional 56.8 billion litres of ethanol by 2015 and an additional 60.6 billion litres of biofuels from cellulosic crops by 2022 (DominguezFaus et al. 2009). These mandated increases will likely increase the demand for groundwater resources, potentially pitting biofuel production against other irrigated agriculture, including food production. In the absence of appropriate governance arrangements to allocate water resources efficiently between uses, this increased competition could have deleterious effects on both the water supply base and commodity prices.

Simultaneously a number of transitions in less developed countries are beginning to revolve around biofuel related opportunities. Many producers are securing land and water resources in developing countries for production of crops, including for export of biofuels (Vermeulen and Cotula 2010; Zoomers 2010). In Africa, for example, agricultural proponents are pointing to little exploited groundwater resources as a major opportunity to expand production (MacDonald et al. 2012). To avoid the depletion of aquifers that has taken place in developed economies, groundwater governance will need to be strengthened in developing countries so as to manage these resources sustainably for both consumptive and non-consumptive purposes.

At the same time, there is a considerable global research effort into second generation biofuels from processing grass or timber cellulose (Sims et al. 2010) and third generation feedstock crops and techniques, which also raises interception questions for aquifer recharge. These 'wonder' crops, like jatropha, are untested. While these species may be able to grow on degraded lands and generate benefits for people in developing countries (Openshaw 2000), it is likely that widespread plantings would more effectively intercept precipitation and reduce aquifer recharge and surface runoff as land is cleared to establish the new crop (van Dijk and Keenan 2007). Proposals for third generation biofuels from farming microbes suggest that saline or wastewater may be used in these processes in the future (Yang et al. 2011), though commercial scale application has yet to be demonstrated. Each technological advance offers improvements in fuel production and may also meet other goals such as a reduction in GHG emissions, but biofuels are intrinsically linked with groundwater resources and can compete directly with agricultural food crops for water and land.

In essence, current commercial biofuel production consumes significant water, for crop production, processing and transport, and if production is increased then pressures to exploit aquifers globally will also increase. Biomass for fuel production where irrigation and crop chemicals are also used results in greater risks of aquifer contamination and hence a potential reduction of economically-usable groundwater. Given the complex and often uncertain knock-on consequences of biofuels, policy interventions which aim to increase biofuel production must account for these risks.

\section{Geothermal}

The generation of electricity from steam from underground aquifers where circulating groundwater is "boiled" by geological heat sources is a commercial 
energy technology and is sustainable in regions with substantial aquifer recharge, such as in Iceland and New Zealand. Geothermal energy proponents are now exploring ways of generating electricity from 'hot rock' sources, where aquifers are small or absent, by injecting water in one borehole to be heated through fractured strata, then extracted as steam up a parallel borehole to generate electricity. Geothermal generation may be sustainable in regions where there is plentiful water but in dry areas the source of water is uncertain. For example, much of the geothermal 'hot rock' resource in Australia is located in arid areas or in the wet-dry tropics where surface water resources are seasonal or absent (Goldstein et al. 2009).

Linking strata through boreholes and by fracking also raises the same questions (as for unconventional gas production) of managing potential risks of natural contaminants becoming incorporated in the production water and moving into previously constrained aquifers through fractures or borehole failures.

\section{Unconventional Gas}

Rising costs of petroleum on international markets, the political drive to achieve greater energy independence, and the development of directional drilling and hydraulic fracturing techniques have significantly improved the economics of natural gas as an energy source. Compared to conventional, free-flowing natural gas extraction, unconventional gas development involves production of methane from multiple types of geological strata where the deposits are dewatered and/or fractured (fracked) to enable withdrawal. This discussion will focus on the two most widespread resources, those in coal seams and those in shale (Cook et al. 2013).

Natural gas is a fossil fuel and governments around the world facilitate its exploitation for reasons of domestic energy security and to reduce greenhouse gas emissions. Scientists disagree on the extent to which unconventional gas production reduces greenhouse gas emissions owing to the risk of fugitive methane leaking from poorly maintained valves and connections in the surface storage and pipe-line infrastructure (Burnham et al. 2011). Nevertheless, in the best case scenario natural gas may reduce greenhouse gas emissions by around half compared to coal-fired generators (Burnham et al. 2011), thus receiving favourable treatment under carbon pricing schemes.

Coal seam, or coal bed, methane deposits are usually closer to the surface and production requires dewatering strata, resulting in the production of lower quality water. Shales with gas potential generally lie deeper in the earth, and gas development and most production methods currently used require the injection of large volumes of water. The directional drilling process and the subsequent hydraulic fracture of the shale target area involve the addition of various chemicals, compounds and proppants which are pumped under pressure to liberate natural gas from the rock formations. Contaminated flow-back water from hydraulic fracturing and 'produce water' (from the geological formations) over the lifetime of the gas well requires careful attention with respect to storage, treatment and disposal so as to avoid contamination risks to both surface and groundwater resources. 
Common concerns for aquifer management for coal seam, coal bed, and shale gas production identified by representatives from industry, researchers and regulators (Williams and Pittock 2012; Mauter et al. 2014), include potential for the creation of pathways for contaminant migration both at depth and from surface infrastructure, toxicity information for fracking chemicals, and to a lesser extent risks from induced seismicity. Fracking chemicals are used to develop and maintain boreholes and prop open the cracks in the strata to allow the gas to flow out. The toxicity of these chemicals is disputed, however many companies involved in the industry are supporting public disclosure laws and practices to demonstrate their confidence that the fluids will cause no harm. There are concerns that fracking may connect different rock strata and enable contaminated water and methane to migrate up into overlying freshwater aquifers, or even to the surface. The industry disputes this concern, saying that fracking is able to be limited to the target, gas producing coal seam or shale strata. However, industry and other stakeholder groups agree that inadequate borehole construction may enable methane and contaminated water to migrate into higher freshwater aquifer and to the surface.

There is a wealth of anecdotal accounts in the news media about the negative environmental impacts of shale-gas development. However, a common concern expressed by many groundwater specialists about gas production, is the lack of hard data and information in relation to migratory pathways. Knowledge and characterization about potential flow paths in the zone between the deep shale targets (usually 2-3 km beneath the surface) and the freshwater aquifer zones that may occur at depths up to $1 \mathrm{~km}$ is limited (Council of Canadian Academies 2014). At the same time, risks from gas related contamination appear to be low, to date very few instances of possible methane migration are documented in the US. Well blowouts (casing failure) are rare because industry standard operating practices require a test of vertical well casing integrity before proceeding with any hydraulic fracturing. Added to this is increased risk of earthquakes induced by the injection of fluids, which in turn compounds the risk of that injected fluid leaking into other aquifers, either during the production of gas or at some later date. However, while research undertaken in the US indicates that injection-via-disposal wells may cause tremors (National Research Council 2013), there is very little evidence hitherto of fault or fracture propagation resulting from hydraulic fracturing.

Industry and many researchers consider that the greatest risk to water resources from gas production is leaks from production water containment ponds and other spills on the surface, including accidents with fluid transport trucks on rural roads (Mauter et al. 2014; Williams and Pittock 2012). Once production water is at the surface it requires treatment, re-use or disposal. In the US, the reinjection of production waters into saline zones in deep geological formations is common practice but not all gas producing areas have the geologic conditions for disposal by injection, and there is increased environmental risk involved in transport to suitable areas. This raises questions as to the risk of polluting potentially beneficial aquifers in other locations. The practice of using closed or evaporative basins to treat production water, especially saline water, was abandoned in Texas as erosion often resulted in the breakdown of containment structures. 
This analysis exposes a number of risks to aquifers from unconventional gas production that each has a technical solution, but only if the industry is consistently well governed and adheres to the highest standards of practice. As a result of public and political concerns, and because of the economic costs related to water use and disposal, the US oil and gas industry is currently researching and field-testing many different on-site water treatment technologies. In addition, technologies that reuse water or actually use zero water for the hydraulic fracturing process are in development. However, until there is a rise in the market value of gas, many of the promising technologies are unlikely to achieve widespread implementation.

One concern that has not yet been well addressed in the development of the unconventional gas industry is the future of groundwater in depleted and abandoned gas fields. Aquifer depletion can be expected over long periods of time if associated with gas deposits, or fractured strata newly capable of holding water will recharge. What is unclear is how this will affect other water resources on basin scales, for example whether other surface and groundwater deposits may be depleted if they begin to fill the new, often deeper voids that are left behind.

\section{Solar Thermal}

Solar thermal power is an emerging technology that uses mirrors in large scale facilities to boil water and generate steam for electricity production. Currently deployed in California and Spain, these power stations work best when located in sunny, arid and semi-arid regions where water is naturally scarce. While the volumes of water required are modest compared with many other forms of energy technologies, sustainable groundwater availability may be a limiting factor for the location of these stations in deserts.

The world's largest solar thermal plant in the Mojave Desert near the border of California and Nevada is the 392-MW Ivanpah project. At the official opening in 2014, the US Energy secretary stated that the station's water needs for steam production "... will use roughly the same amount of water as two holes at the nearby golf course" (Phillips 2014). An additional water demand from the desert aquifers will be to regularly wash dust from the project's 347,000 mirrors.

As with all thermal power stations, there is the option of deploying dry rather than wet cooling technology. Dry cooling systems use less than $10 \%$ of the water of a wet cooling system but have several drawbacks, including a higher, upfront capital cost; reduction in energy generation of around $8 \%$; and less effective operation with higher air temperatures, such as the arid areas where these power stations are located (DoE 2008).

Ivanpah uses a directly heated steam cycle that can only generate power when the sun shines. In the future, large-scale solar plants will likely use an energy storage technology (such as the process that heats molten salt) so that energy can be stored and then 'released' whenever there is a load demand (Phillips 2014). Globally, large schemes have been proposed to power countries like Australia (BZE 2010) or whole regions such as northern Africa and Europe based on solar thermal power stations, though the economies of such ventures has yet to prove favourable. 
Production of hydrogen for use as a renewable fuel in fuel cells, from the electrolysis of water using solar generated electricity, is another possibility. If this hydrogen is combined with atmospheric nitrogen at high temperatures (which is possible in a solar thermal power station) to produce ammonia $\left(\mathrm{NH}_{3}\right)$ as a renewable energy fuel, it could regenerate the water, but some loss of water might be expected (Andrews and Shabani 2012; Balat 2008).

\section{Aquifer Thermal Energy Systems}

Aquifer thermal energy storage systems (ATES) are common in Europe and typically operate by running groundwater through a cooling tower in winter and returning it to the aquifer for storage. In summer, the chilled water is withdrawn, used for air conditioning and put back into the aquifer as warm water for use in winter to reduce heating costs. If closed loops are used to transfer heat the loop pipes are typically filled with food-grade glycol so that in the unlikely event of a leak, there is minimal risk to groundwater quality. Now, there is a growing trend in the US for using ground source heating and cooling technology for individual homes, schools, churches and office buildings. There are already over one million such installations in operation in the US. Ball State University in Muncie, Illinois has installed a ground source system involving 3,600 boreholes to service $622,450 \mathrm{~m}^{2}$ of building space which will save the burning of $36,000 \mathrm{t}$ of coal that was previously used each year (Roulo 2011).

When applied on a large scale for college campuses, military installations etc. this technology is providing a developing field for hydrogeologists to characterize subsurface heat transfer capabilities and to assess potential impacts on aquifers, particularly if the heat dissipation is dependent on groundwater flow. A concern is the potential build-up of groundwater temperatures which could progressively decrease heat transfer efficiency.

ATES technology and ground source heating and cooling raise a number of issues for future groundwater management. As with other technologies, their rapid increase in popularity since the 1990s has seen deployment in advance of adequate regulatory oversight (Bonte et al. 2011). Both systems can interfere with other underground infrastructure for electricity, water distribution and telecommunications technologies. The technology also raises questions of who owns the underground lands and waters and under what circumstances they can be exploited. The open systems risk diminishing biological and chemical water quality of aquifers through moving water about, and heating and cooling. The closed systems raise questions as to standards for containing the chemicals used and responsibilities for leaks and decommissioning.

\section{Fossil Substitution}

As the above examples illustrate, new energy technologies offer opportunities to reduce greenhouse gas emissions but with some risks for groundwater resources. A number of the proponents of these newer technologies argue that they can be substitutes for water-intensive fossil fuel-fired power stations and thus may free up water for other uses. For example, Beyond Zero Emissions argues that its 
proposal for a solar thermal power station in Port Augusta, Australia can be watered by decommissioning the local coal-fired power station (BZE 2010). Certainly in regions with high concentration of coal-fired power stations this may free up water, for example, in the Latrobe and Hunter valleys in Australia. However, this may also shift water consumption from places where water use is well-regulated to places where governance is poorer, for instance, from the two Australian coastal valleys to arid locations in the interior, where each litre of water may have more environmental and socio-economic value to other users. If governments and societies want this sort of water substitution to occur, then it will require active facilitation and regulation.

\subsubsection{Risks to Groundwater from Carbon Sequestration in the Landscape}

Carbon sequestration in the landscape, a subset of geoengineering proposals, is another component of mitigation policies that may impact on groundwater management and use. Two approaches to store greenhouse gases in the landscape are discussed here: geological carbon capture and storage, and carbon farming, including plantations.

Carbon dioxide $\left(\mathrm{CO}_{2}\right)$ capture and sequestration (CCS) is a process that involves underground injection and geologic storage (sequestration) of $\mathrm{CO}_{2}$ in deep underground rock formations that are overlain by impermeable rock that trap the $\mathrm{CO}_{2}$ and prevent it from migrating upward. CCS can significantly reduce emissions from industrial sources such as fossil fuel-fired power plants (EPA 2013). The US Department of Energy estimates that between 1,800 and 20,000 billion metric tons of $\mathrm{CO}_{2}$ could be stored underground in the US (c, 2012), a volume that is equivalent to 600-6,700 years of current level emissions from large stationary sources in the US (GHGRP 2012). Moreover, while sequestration removes $\mathrm{CO}_{2}$, that might otherwise impact the atmosphere, according to the US EPA Greenhouse Gas Reporting Program, $\mathrm{CO}_{2}$ capture for industrial reuse is currently occurring at over 120 facilities in the US. End users of $\mathrm{CO}_{2}$ include enhanced oil recovery, food and beverage manufacturing, pulp and paper manufacturing, and metal fabrication.

The success of CCS requires very low rates of leakage. The widespread drilling of gas wells has been cited as a risk to the security of potential CCS sites (Elliot and Celia 2012) and widespread bore-holes used previously in searches for oil and other minerals may also cause leakages. Thousands of such bore-holes were drilled in the early twentieth century, and their precise locations and seals are often unknown. In terms of groundwater, the primary concern is whether placement of waste gases underground will result in reductions of groundwater quality.

In contrast with CCS, sequestration of carbon in land and vegetation is practised internationally. In some nations, it is used either to earn or sell carbon credits in a formal market or in schemes to offset emissions in other sectors. As an example, many airlines now offer passengers the option of paying extra to offset the emissions from their flights through tree planting.

Planting trees to sequester carbon is the most common method advanced because of its many co-benefits, in terms of such services as biodiversity and soil 
conservation, production of non-timber forest products, and aesthetic improvements to the landscape. However, forests will normally intercept more precipitation than non-forested land uses, diminishing surface runoff into streams and aquifer recharge (van Dijk and Keenan 2007; Jackson et al. 2005). This inflow interception may not have significant impacts in wet environments such as in the wet tropics, but in the temperate zone significant reductions in flows are likely. In past decades in Australia, tree planting has been actively encouraged to reduce groundwater recharge in areas subject to salinity. Several means of reducing these impacts on water resources are possible, including: incorporating the plantation sector into cap and trade water markets, as occurs in South Australia and South Africa; limiting afforestation to landscapes where the impacts may be acceptable, such as the wet tropics and salinity prone lands; or scheduling planting over decades so that the impacts are spread over a longer period of time (Pittock et al. 2013).

A number of other methods are being actively promoted to sequester more carbon in soils, although there is little evidence of widespread application thus far. Incorporating more biomass into soils is promoted as a way of enhancing agricultural productivity by improving soil structure, fertility and water infiltration, as well as sequestering carbon (Henriksen et al. 2011). Biochar - adding charcoal to soils - has a very active group of promoters (Kleiner 2009; Sohi et al. 2009). A lot of research investment has focussed at the field scale on the longevity of the carbon sequestration with often disappointing results (Lam et al. 2013). A common claim is that by developing more friable soils that these methods will enable more precipitation to be stored in the soil and advantage crop growth. If this proves to be the case one potential outcome is diminished surface runoff and aquifer recharge.

Internationally, carbon sequestration in the landscape has a mandate under the umbrella of 'land use change and forestry' and it is being deployed through two programs of the UN Framework Convention on Climate Change. The Clean Development Mechanism and proposed REDD+ scheme (Reduced Emissions from Degradation and Deforestation plus) enable projects applying approved methodologies for reducing emissions or sequestering carbon in land and vegetation in developing countries to generate carbon credits (CDM Executive Board 2010; Pritchard 2009). However, the Clean Development Mechanism's current procedures for assessing and considering any negative impacts of proposed projects on water resources are token (Pittock 2010).

Australia is one nation that has legislated in the Carbon Credits (Carbon Farming Initiative) Act 2012 for market-based carbon sequestration in the landscape, based on the Clean Development Mechanism's approach of approved methodologies (Australian Government 2011). The Act's regulations attempt to limit the impact of carbon plantations on water by prohibiting commercial timber production and planting in areas within the $600 \mathrm{~mm} / \mathrm{year}$ and above rainfall isohyet, subject to a number of exemptions (DCCEE 2011). The $600 \mathrm{~mm} / \mathrm{year}$ rainfall isohyet was chosen as a threshold above which surface water runoff may be expected, however this may unreasonably restrict planting in environments where impacts may be insignificant, as in the tropics. The exemptions include planting for biodiversity conservation, and those agreed by poorly-resourced, state government mandated 
natural resource management organisations. National policy agreements to include significant inflow interception activities (including groundwater recharge) within cap and trade water markets have only been implemented by one of the eight states and territories (NWC 2011). Consequently this odd collection of half implemented policies and the exemptions mean that there is a strong prospect of perverse impacts on groundwater recharge.

Many other nations have prioritised reforestation in their climate mitigation policies, including China, India and Mexico, indicating that managing the tradeoffs between planting for carbon sequestration and water use is a growing global challenge (Pittock 2011). The links between the projected impacts of climate change and the sustainable management of surface and groundwater resources makes the challenge all the more complex. For example, with so many countries pursuing carbon sequestration through tree plantings, and the Intergovernmental Panel on Climate Change's projections for increased wildfire frequency and intensity, it is not inconceivable that governments may be increasing the risks of even bigger and more devastating wildfires by pursuing policies that are, ironically, attempting to mitigate the impacts of climate change. And, of course, the knockon consequences of more frequent and intense wildfires are insidious: denuded catchments which in turn lead to more floods, erosion and siltation of water storages, which has important implications for the sustainable use of groundwater resources.

\subsubsection{Climate Change Adaptation Policies}

Having discussed the implications of climate change mitigation on groundwater resources, we now turn to consider how groundwater may be used and sustained through climate change adaptation measures. Climate change is likely to impact surface water supplies in particular places in a number of ways, including: increasing or decreasing precipitation; changing seasonality of snowmelt and river flows; increasing evapotranspiration, the intensity of storms and frequency of floods and droughts. Groundwater resources have the potential to complement or buffer surface water shortages to deliver key services (Bates et al. 2008). Three examples are now elaborated, namely urban water supply, food production and freshwater biodiversity conservation.

\subsubsection{Water Supply}

Sustaining a reliable supply of drinking water to urban areas is essential for the well-being of the majority of the planet's people. Not only does good health depend on clean drinking water, but so too does the economic health of these communities. Climate change impacts, increasingly, jeopardise cities that depend on surface water catchments. Australia provides a salutary example. In the mid-1970s inflows into the city of Perth's water storages began a series of 'step changes' such that a decline in the order of $70 \%$ of the previous long-term average was experienced (Petrone et al. 2010). During the 2002-2010 Millennium Drought another five cities 
in southern Australia also saw their water storages reduced to perilously low levels. A common response of the impacted states was to diversify the supplies of water for these cities by adding reuse, groundwater, and desalination sources. In particular, Adelaide, Perth and Sydney each drew on new groundwater resources, applied managed aquifer recharge, or set aside aquifers as drought reserves.

This Australian example highlights the potential of aquifers to grow in importance as existing urban water storage and sources become more sensitive to increasingly variable climatic and surface hydrological conditions. This capacity can be enhanced through managed aquifer recharge, as detailed in Chaps. 17 and 18. These same storage characteristics will also make aquifers more attractive as a source of water for food production.

Additionally, an important buffering role of groundwater can be provided by individual on-site water wells. Private wells can reduce demand pressures on larger aquifers. In the US over 40 million people are supplied with their water needs from 15 million private wells (US Census Bureau 2007). In most instances homeowner wells (often in bedrock fractures) are accessing small discrete aquifer systems that are economically unusable for any major supply. Provided there is limited outside lawn watering, virtually all the pumped water is treated and returned to the sub-surface via septic systems and leach-fields. The key to continuing this harmonious use of groundwater is to ensure through zoning regulations that well density does not exceed renewability and that the rights of private well owners sharing access to aquifers with major pumpers are protected. "Deepest well wins" is not a good basis for groundwater management.

\subsubsection{Irrigated Food Production}

In 2007, the International Water Management Institute (IWMI)'s "Comprehensive assessment of water management in agriculture" (CAoWMiA) reviewed the world's future food needs and explored scenarios for how the required water may be sourced (CAoWMiA 2007). Around half of the globally accessible freshwater is already diverted for human uses and $70 \%$ of the world's water consumption is in agricultural production. CAoWMiA (2007) reported that food demand will double over the next 50-80 years, and that without improvements in productivity, water use in food production will need to increase by $70-90 \%$ under a changing climate (CAoWMiA 2007). From a business perspective, a McKinsey \& Company global report estimates "that the annual pace at which supply is added over the next 20 years in water and land would have to increase by $140 \%$ and up to $250 \%$, respectively, compared with the rate at which supply expanded over the past two decades. This expansion of supply could have a wide range of potentially negative effects on the environment. In this case, there would be an additional $1,850 \mathrm{~km}^{3}$ of water consumption by 2030, $30 \%$ higher than today's levels ..." (Dobbs et al. 2011: 8).

A study by Wada et al. (2012) shows that on a global basis non-renewable groundwater abstraction represents $18 \%$ of global gross irrigation water demand. In other words, on a global basis we are draining aquifer systems (see also Chap. 2 for more detail on aquifer depletion). This loss of groundwater inventory has 
greatly reduced the capacity of aquifers to serve as a buffer against current or future drought.

In the US over the last 100 years over $1,000 \mathrm{~km}^{3}$ of groundwater has been removed from major aquifers with the greatest losses from the High Plains Aquifer $\left(350 \mathrm{~km}^{3}\right)$ and California's Central Valley $\left(150 \mathrm{~km}^{3}\right)$ (Konikow 2013). These trends in groundwater depletions in the US have been observed and known for many years. However, effective and sustainable management strategies have eluded policy makers and only now, because of severe drought conditions, are end users and legislators in California, Texas and other impacted states beginning to talk about water metering and devising workable criteria for prioritizing allocations of the progressively scarce groundwater resources. These discussions are clouded by the issue of "water rights" and the spectre of litigation from end-users whose pumping might be curtailed.

The Asian Development Bank raises similar concerns. Noting "total annual sustainable freshwater supply remaining static at 4,200 billion cubic meters $\left(\mathrm{m}^{3}\right)$, the annual deficit for 2030 is forecasted to be 2,765 billion $\mathrm{m}^{3}$, or $40 \%$ of unconstrained demand, assuming that present trends continue. India and China are forecasted to have a combined shortfall of 1,000 billion $\mathrm{m}^{3}$ - reflecting shortfalls of $50 \%$ and $25 \%$, respectively. There is little evidence of changing trends. Signals of scarcity and stress have had little impact on policies, demand, or the market. On the supply side, there is little room for finding and abstracting more water. In areas with physical water scarcity (including north [China], south and northwest India, and Pakistan), demand needs to lessen" (ADB 2013: vi).

The increasingly frequent droughts predicted with climate change means that the greater security of food production afforded by irrigation will become increasingly popular. In Africa, for example, national governments have extensive plans to expand irrigated production (Sullivan and Pittock 2014). There has been extensive debate about why irrigated agriculture has performed very poorly in Africa, which points to a combination of problems with infrastructure, human capacity and economic viability (Lankford 2009). A number of researchers have pointed to extensive, but little used, groundwater resources in Africa as the basis for increased agricultural production (MacDonald et al. 2012). The arguments for greater use of groundwater are many, but the most compelling are the increased cost efficiencies and drought resilience gained over traditional small-scale rainwater harvesting, and the capacity for groundwater resources to be developed to support more people across the landscape compared to centralised, surface irrigation schemes (Stirzaker and Pittock 2014).

The obvious question about greater reliance in Africa on groundwater for agriculture is how to avoid the over-exploitation that has afflicted many parts of the world. The management of consumption using cap and trade groundwater markets as practised in Australia is unlikely to work in most of Africa where the reach of the state is not as strong. Work by the International Water Management Institute in regions of over-exploited groundwater in India indicates two examples of unconventional approaches that may be addressing the problem of over-exploitation of groundwater due to subsidized electricity for pumping. Reducing these 
power subsidies has not been politically feasible but other solutions have emerged. Over the past decade in Gujarat, India a USD \$260 million scheme called Jyotigram Yojana ("Lighted Village") has sought to overcome electricity theft and blackouts while rationing groundwater and ensuring the financial viability of utilities (IWMI 2011). Installation of a dual electricity distribution system has enabled one distribution system to be dedicated to providing reliable supplies to villages while the other system provides power for $8 \mathrm{~h} /$ day to groundwater pumps. This approach has curtailed energy consumption, encouraged more efficient groundwater pumping, and facilitated a tripling of agricultural production.

More recently the state government of West Bengal scrapped a permit system, instead connecting small pumps to the power grid at a fixed cost that only enables farmers to access annual monsoon recharge from shallow aquifers, conserving deeper groundwater resources. IWMI estimate that the area irrigated will expand in 3-5 years from 2.98 to 4.83 million hectares, increasing annual paddy rice production by 4.62 million tonnes (IWMI 2012).

\subsubsection{Freshwater Biodiversity Conservation}

Freshwater biodiversity has been significantly impacted by overexploitation of surface and groundwaters (MEA 2005; see also Chaps. 14 and 15). Current approaches to conserving freshwater biodiversity, including for climate change adaptation, have focussed on providing surface environmental flows and in some countries, environmental water demand management (also called environmental works and measures in Australia) (Poff and Matthews 2013; Pittock and Lankford 2010; Richter 2010). In countries like Australia, environmental flow programs have focussed on conserving large wetland systems, often in the lower reaches of river systems (Pittock and Finlayson 2011). An assumption is that surface water environment flows under conditions of short-term variability, and long-term climate change, will be sufficient to sustain the ecological character of these wetlands. Yet evidence is that desiccation and water quality impacts of drought events, exacerbated by climate change, are not adequately ameliorated by the current environmental watering programs (Pittock 2013; Pittock et al. 2010). In particular, these strategies assume that large wetlands in downstream reaches of river basins and ecosystems can be maintained in a similar state to the present.

Contrary to this approach, there is an emerging focus on the importance of conserving groundwater flows as a key strategy for retaining freshwater biota in refugia during severe drought and climate change (Pittock and Finlayson 2011). The potential exists for groundwater inflows into river channels to maintain reaches with sufficient volumes of water of acceptable quality to sustain biota that may otherwise perish. There are numerous management challenges if this adaptation option is to succeed, not least gaining community support to conserve connected aquifers for this purpose (Lukasiewicz et al. 2013). Importantly, these refugia are often different to the freshwater habitats currently prioritised for conservation. For instance, in Australia's Murray-Darling Basin, gaining reaches are often located in the mid and upper river systems rather than the downstream wetlands currently favoured (CSIRO 2008; Pittock and Finlayson 2011). 
This example of changing groundwater management priorities highlights the governance challenges brought on by global change.

\subsection{Discussion and Conclusion}

The need for Integrated Groundwater Management (IGM) is set out in the first chapter of this volume and defined as: "a structured process which promotes the coordinated management of groundwater and related resources (including conjunctive management with surface water), taking into account non-groundwater policy interactions, in order to achieve shared economic, social welfare and ecosystem outcomes."

Groundwater governance arrangements available to policy-makers vary from the local to global scales (see Part II which is devoted to governance issues). International scale processes, such as climate change, may have major impacts on groundwater at the national scale. Similarly policy decisions at the national scale on natural resources management, such as on the extent of forests, will impact on aquifers. Groundwater systems are usually sub-national in scale such that sound national policy will only be effective if it supports sustainable management at the regional or local levels. Implementation of effective policies will require fostering of human capacity and institutions at appropriate levels, international to local scale. The earlier discussion also highlights the importance of integrating interventions across sectors. For example, managing groundwater sustainably may require intervention in the food sector more than the water sector. What then are some of the key mechanisms that may facilitate sustainable groundwater management? Is there a case for IGM, to complement Integrated Water Resources Management (IWRM; and its various iterations)?

As this chapter has elucidated, sustainable management of aquifers across competing water-use sectors requires positive synergies to be seized and perverse impacts to be identified and minimised. IGM under global change requires four key interventions (Pittock et al. 2013; Hussey and Pittock 2012; Pittock et al. 2015):

1. Information. The often unseen nature of groundwater and the lack of a common currency with competing natural resource uses can lead to decisions with deleterious impacts on aquifers. We contend that making publicly available, and generating where necessary, compatible information on groundwater resources and major uses like the environment, energy, food and domestic water can facilitate integrated decision making. Examples of such information transparency include: publicly available water accounts, such as those of the Australian Bureau of Meteorology (BoM and ABS 2011); the Australian Government's online atlas of matters of national environmental significance that includes listed groundwater dependent biota (DOE n.d.); simple, online decision making models, such as one in Texas that enables businesses and regulators to match water resources to proposed power generators (Webber 
Energy Group n.d.); and 'traffic light' status reports on the state of aquifers and other resources (Pittock et al. 2013).

2. Technology. There are many technologies that may use less groundwater while facilitating climate change mitigation and adaptation, such as dry cooling thermal power stations (NETL 2008) and more efficient irrigation equipment (Mushtaq et al. 2009).

3. Market incentives. Establishing cap and trade water markets can create powerful incentives for using groundwater more efficiently and sustainably, as is now practised in many parts of Australia (Grafton et al. 2011). However, given the lower price of water per volume compared to many other natural resources and the potential for externalities, it is essential that markets for natural resources such as water, timber and carbon are harmonised to prevent negative impacts on groundwater (Pittock et al. 2013).

4. Reforming governance. Systematically integrating decisions across sectors like water and climate policy will expose many of the perverse outcomes identified in this chapter, though such integration is difficult to achieve. Pittock (2011) argues that there are five attributes of integrated governance, namely: (i) leadership; (ii) legal mandates for agencies to work across sectors in the interests of sustainability, for example, for electricity utilities to use fees to conserve water; (iii) mechanisms for vertical integration for local to national and international institutions, such as Australia's National Water Initiative (Commonwealth of Australia et al. 2004); (iv) horizontal integration between sectoral agencies, such as inter-departmental committees; and (v) accountability mechanisms such as periodic reviews, auditors, and capacity for third parties to challenge unsustainable decisions in the courts. As the examples discussed above with underground thermal energy systems and unconventional gas highlight, such integration is particularly required when new technologies emerge, to establish frameworks to govern their deployment.

Combined, actions in these four areas will go a long way to managing groundwater resources sustainably. However, the complexity of sustainable groundwater management raises the obvious question of whether an overarching conceptual framework is needed, as was deemed the case nearly 30 years ago when IWRM emerged. Indeed, espousing as it does "the coordinated development and management of water, land and related resources, in order to maximize the resultant economic and social welfare in an equitable manner without compromising the sustainability of vital ecosystems" (GWP 2000), IWRM does in principle at least incorporate groundwater resources. In practice, though, the emphasis of IWRM has been on surface water resources, with scant attention afforded to groundwater - a fact which is borne out by the excellent chapters in this book. However, advocates of an IGM framework should be aware of IWRM's limitations. While there is evidence of broad acceptance of IWRM principles, success has been limited. Three particular deficiencies will likely be relevant in any attempt at IGM. First, the acceptance of IWRM has not changed the underlying power differences between stakeholders that make integrated management, and more sustainable outcomes, so 
difficult to achieve. Second, as an all-encompassing framework IWRM is intellectually robust but practically very difficult to implement. Finally, conceptual frameworks do not address the underlying governance and institutional capacity challenges that beset many developing countries, and which are, arguably, the major barrier to more sustainable practices. It is salient that many proponents of IWRM have been calling for a new approach for the last decade (Biswas 2004).

There is value in an overarching framework to manage groundwater resources, but perhaps more importantly there is a need for the advocates of IGM to engage stakeholders 'out of the water box', with a view to advocating the four interventions listed above. Global changes are increasing the pressures on groundwater resources, but with these difficult problems and crises come policy reform windows. The challenge for decision-makers and water managers is to be prepared to seize the opportunities to implement more sustainable groundwater management.

Open Access This chapter is distributed under the terms of the Creative Commons AttributionNoncommercial 2.5 License (http://creativecommons.org/licenses/by-nc/2.5/) which permits any noncommercial use, distribution, and reproduction in any medium, provided the original author(s) and source are credited.

The images or other third party material in this chapter are included in the work's Creative Commons license, unless indicated otherwise in the credit line; if such material is not included in the work's Creative Commons license and the respective action is not permitted by statutory regulation, users will need to obtain permission from the license holder to duplicate, adapt or reproduce the material.

\section{References}

ADB (2013) Thinking about water differently: managing the water-food-energy nexus. Asian Development Bank, Manilla

Andrews J, Shabani B (2012) Re-envisioning the role of hydrogen in a sustainable energy economy. Int J Hydrogen Energy 37(2):1184-1203. doi:10.1016/j.ijhydene.2011.09.137

Australian Government (2011) Carbon Credits (Carbon Farming Initiative) Act 2011, No. 101, An Act about projects to remove carbon dioxide from the atmosphere and projects to avoid emissions of greenhouse gases, and for other purposes. Commonwealth of Australia, Canberra

Balat M (2008) Potential importance of hydrogen as a future solution to environmental and transportation problems. Int J Hydrogen Energy 33(15):4013-4029. doi:10.1016/j.ijhydene. 2008.05.047

Bates BC, Kundzewicz ZW, Wu S, Palutikof JP (eds) (2008) Climate change and water, Technical paper of the Intergovernmental Panel on Climate Change. IPCC Secretariat, Geneva

Biswas AK (2004) Integrated water resources management: a reassessment. Water Int 29(2): 248-256. doi:10.1080/02508060408691775

BoM, ABS (2011) Australian Government water accounting, Activities of the Bureau of Meteorology and the Australian Bureau of Statistics. Bureau of Meteorology and Australian Bureau of Statistics, Melbourne/Canberra

Bonte M, Stuyfzand PJ, Hulsmann A, Van Beelen P (2011) Underground thermal energy storage: environmental risks and policy developments in the Netherlands and European Union. Ecol Soc 16(1):22. http://www.ecologyandsociety.org/vol16/iss1/art22/ 
Burnham A, Han J, Clark CE, Wang M, Dunn JB, Palou-Rivera I (2011) Life-cycle greenhouse gas emissions of shale gas, natural gas, coal, and petroleum. Environ Sci Technol 46(2):619-627. doi:10.1021/es201942m

BZE (2010) Zero carbon Australia stationary energy plan. Beyond Zero Emissions, Melbourne

CAoWMiA (2007) Water for food, water for life. A comprehensive assessment of water management in agriculture. Earthscan and International Water Management Institute, London/ Colombo

CDM Executive Board (2010) Project design document form for afforestation and reforestation project activities (CDM-AR-PDD), version 05. UN Framework Convention on Climate Change, Bonn

Commonwealth of Australia, Government of New South Wales, Government of Victoria, Government of Queensland, Government of South Australia, Government of the Australian Capital Territory, Government of the Northern Territory (2004) Intergovernmental agreement on a national water initiative. Council of Australian Governments, Canberra

Cook P, Beck V, Brereton D, Clark R, Fisher B, Kentish S, Toomey J, Williams J (2013) Engineering energy: unconventional gas production. Australian Council of Learned Academies, Melbourne

Council of Canadian Academies (2014) Environmental impacts of shale gas extraction in Canada. Council of Canadian Academies, Ottawa

CSIRO (2008) Water availability in the Murray-Darling Basin, A report from CSIRO to the Australian Government. CSIRO, Canberra

DCCEE (2011) Carbon credits (carbon farming initiative) regulations 2011. Department of Climate Change and Energy Efficiency, Canberra

Dobbs R, Oppenheim J, Thompson F, Brinkman M, Zornes M (2011) Resource revolution: meeting the world's energy, materials, food, and water needs. McKinsey \& Company, Chicago

DoE (2008) Concentrating solar power commercial application study: reducing water consumption of concentrating solar power electricity generation, Report to congress. US Department of Energy, Golden

DOE (n.d.) Protected matters search tool. Department of the Environment, Canberra

Dominguez-Faus R, Powers SE, Burken JG, Alvarez PJ (2009) The water footprint of biofuels: a drink or drive issue? Environ Sci Technol 43(9):3005-3010. doi:10.1021/es802162x

Elliot TR, Celia MA (2012) Potential restrictions for $\mathrm{CO}_{2}$ sequestration sites due to shale and tight gas production. Environ Sci Technol 46(7):4223-4227. doi:10.1021/es2040015

EPA (2013) Carbon dioxide capture and sequestration. United States Environmental Protection Agency, Washington, DC

Gerbens-Leenes PW, Hoekstra AY, van der Meer TH (2008) Water footprint of bio-energy and other primary energy carriers, The value of water research report series no 29. UNESCO-IHE Institute for Water Education, Delft

Goldstein B, Hill A, Long A, Budd A, Holgate F, Malavazos M (2009) Hot rock geothermal energy plays in Australia. In: Proceedings of the 34th workshop on geothermal reservoir engineering, Stanford University, Stanford

Grafton RQ, Libecap G, McGlennon S, Landry C, O’Brien B (2011) An integrated assessment of water markets: a cross-country comparison. Rev Environ Econ Policy 5(2):219-239. doi:10. 1093/reep/rer002

Greenhouse Gas Reporting Program (GHGRP) (2012) EPA Greenhouse Gas Reporting datasubpart PP-suppliers of carbon dioxide. US Environmental Protection Agency, Washington, DC, http://www2.epa.gov/ghgreporting

Henriksen CB, Hussey K, Holm PE (2011) Exploiting soil-management strategies for climate mitigation in the European Union: maximizing "win-win" solutions across policy regimes. Ecol Soc 16(4). doi:10.5751/ES-04176-160422

Hirabayashi Y, Mahendran R, Koirala S, Konoshima L, Yamazaki D, Watanabe S, Kim H, Kanae S (2013) Global flood risk under climate change. Nature Clim Change, advance online publication. 
doi:10.1038/nclimate1911, http://www.nature.com/nclimate/journal/vaop/ncurrent/abs/ nclimate1911.html\#supplementary-information

Hussey K, Pittock J (2012) The energy-water nexus: Managing the links between energy and water for a sustainable future. Ecol Soc 17(1):31 [online]. doi:10.5751/ES-04641-170131

IPCC (2007a) Climate Change 2007: impacts, adaptation and vulnerability, Working Group II contribution to the fourth assessment report of the Intergovernmental Panel on Climate Change. International Panel on Climate Change, Geneva

IPCC (2007b) Mitigation of climate change: summary for policymakers, Contribution of Working Group III to the fourth assessment report of the Intergovernmental Panel on Climate Change. Intergovernmental Panel on Climate Change, Geneva

IWMI (2011) Innovative electricity scheme sparks rural development in India's Gujarat State. Success Stories (9). http://www.iwmi.cgiar.org/Publications/Success_Stories/PDF/2011/Issue_9-Innova tive $\% 20$ electricity\%20scheme\%20sparks.pdf

IWMI (2012) Boosting water benefits in West Bengal. Success Stories (14) http://www.iwmi. cgiar.org/Publications/Success_Stories/PDF/2011/Issue_14-Groundwater_in_West_Bengal. pdf

Jackson RB, Jobbágy EG, Avissar R, Roy SB, Barrett DJ, Cook CW, Farley KA, le Maitre DC, McCarl BA, Murray BC (2005) Trading water for carbon with biological carbon sequestration. Science 310(5756):1944-1947. doi:10.1126/science.1119282

King CW, Webber ME (2008) Water intensity of transportation. Environ Sci Technol 42(21): 7866-7872

Kleiner K (2009) The bright prospect of biochar. Nature (0906):72-74

Konikow LF (2013) Groundwater depletion in the United States (1900-2008). US Department of the Interior, US Geological Survey, Reston, pp 2013-5079. http://pubs.usgs.gov/sir/2013/5079/

Lam SK, Chen D, Mosier AR, Roush R (2013) The potential for carbon sequestration in Australian agricultural soils is technically and economically limited. Sci Rep 3. doi:10.1038/srep02179, http://www.nature.com/srep/2013/130710/srep02179/abs/srep02179.html\#supplementaryinformation

Lankford B (2009) Viewpoint - the right irrigation? Policy directions for agricultural water management in Sub-Saharan Africa. Water Altern 2(3):476-480

Lukasiewicz A, Finlayson CM, Pittock J (2013) Identifying low risk climate change adaptation in catchment management while avoiding unintended consequences. National Climate Change Adaptation Research Facility, Gold Coast

MacDonald AM, Bonsor HC, Dochartaigh BÉÓ, Taylor RG (2012) Quantitative maps of groundwater resources in Africa. Environ Res Lett 7(2):024009

Mauter MS, Alvarez PJJ, Burton A, Cafaro DC, Chen W, Gregory KB, Jiang G, Li Q, Pittock J, Reible D, Schnoor JL (2014) Regional variation in water-related impacts of shale gas development and implications for emerging international plays. Environ Sci Technol. doi:10.1021/ es405432k

Millennium Ecosystem Assessment (MEA) (2005) Ecosystems and human well-being: wetlands and water synthesis. World Resources Institute, Washington, DC

Mushtaq S, Maraseni TN, Maroulis J, Hafeez M (2009) Energy and water tradeoffs in enhancing food security: a selective international assessment. Energy Policy 37(9):3635-3644

National Research Council (2013) Induced seismicity potential in energy technologies. The National Academies Press, Washington, DC

NETL (2008) Estimating freshwater needs to meet future thermoelectric generation requirements, 2008 update. DOE/NETL-400/2008/1339, September 30. US Department of Energy, National Energy Technology Laboratory, Pittsburgh

Notaras M (2011) All biofuel policies are political. Our World, 18 Feb 2011) [online]

NWC (2011) The national water initiative - securing Australia's water future: 2011 assessment. National Water Commission, Canberra

Openshaw K (2000) A review of Jatropha curcas: an oil plant of unfulfilled promise. Biomass Bioenerg 19(1):1-15. doi:10.1016/S0961-9534(00)00019-2 
Petrone KC, Hughes JD, Van Niel TG, Silberstein RP (2010) Streamflow decline in southwestern Australia, 1950-2008. Geophys Res Lett 37(11), L11401. doi:10.1029/2010GL043102

Phillips A (2014) World's largest solar thermal plant uses as much water as two holes on nearby golf course. Climate Progress, 13 Feb 2014 [online]

Pittock J (2010) A pale reflection of political reality: integration of global climate, wetland, and biodiversity agreements. Climate Law 1(3):343-373

Pittock J (2011) National climate change policies and sustainable water management: conflicts and synergies. Ecol Soc 16(2):25 [online]

Pittock J (2013) Lessons from adaptation to sustain freshwater environments in the MurrayDarling Basin, Australia. Wiley Interdiscip Rev Clim Change 4(6):429-438. doi:10.1002/wcc. 230

Pittock J, Finlayson CM (2011) Australia's Murray-Darling Basin: freshwater ecosystem conservation options in an era of climate change. Mar Freshw Res 62:232-243

Pittock J, Lankford BA (2010) Environmental water requirements: demand management in an era of water scarcity. J Integr Environ Sci 7(1):75-93. doi:10.1080/19438151003603159

Pittock J, Finlayson CM, Gardner A, McKay C (2010) Changing character: the Ramsar convention on wetlands and climate change in the Murray-Darling Basin, Australia. Environ Plan Law J 27(6):401-425

Pittock J, Hussey K, McGlennon S (2013) Australian climate, energy and water policies: conflicts and synergies. Aust Geogr 44(1):3-22. doi:10.1080/00049182.2013.765345

Pittock J, Hussey K, Dovers, S (eds) (2015) Climate, energy and water. Cambridge University Press, Cambridge

Poff NL, Matthews JH (2013) Environmental flows in the Anthropocence: past progress and future prospects. Curr Opin Environ Sustain 5(6):667-675. doi:10.1016/j.cosust.2013.11.006

Pritchard D (2009) Reducing emissions from deforestation and forest degradation in developing countries (REDD) - the link with wetlands. Foundation for International Environmental Law and Development, London

Richter BD (2010) Re-thinking environmental flows: from allocations and reserves to sustainability boundaries. River Res Appl 26(8):1052-1063. doi:10.1002/rra.1320

Rogelj J, McCollum DL, Riahi K (2013) The UN's 'Sustainable Energy for All' initiative is compatible with a warming limit of $2^{\circ} \mathrm{C}$. Nat Clim Change 3(6):545-551. doi:10.1038/ nclimate 1806

Roulo C (2011) Ball State University's geothermal system will be largest in US Contractor (5 December 2011) [online]

Sims RE, Mabee W, Saddler JN, Taylor M (2010) An overview of second generation biofuel technologies. Bioresour Technol 101(6):1570-1580

Sohi S, Loez-Capel E, Krull E, Bol R (2009) Biochar's roles in soil and climate change: a review of research needs, CSIRO land and water science report 05/09. CSIRO, Canberra

Stirzaker R, Pittock J (2014) The case for a new irrigation research agenda for Sub-Saharan Africa. In: Pittock J, Grafton RQ, White C (eds) Water, food and agricultural sustainability in Southern Africa. Tilde University Press, Prahran, pp 91-107

Sullivan A, Pittock J (2014) Agricultural policies and irrigation in Africa. In: Pittock J, Grafton RQ, White C (eds) Water, food and agricultural sustainability in Southern Africa. Tilde University Press, Prahran, pp 30-54

U.S. Census Bureau (2007) American Housing Survey for the United States. Current Housing reports, Series H150/07. U.S. Government Printing Office, Washington, DC

van Dijk AIJM, Keenan RJ (2007) Planted forests and water in perspective. For Ecol Manage 251(1-2):1-9

Vermeulen S, Cotula L (2010) Over the heads of local people: consultation, consent, and recompense in large-scale land deals for biofuels projects in Africa. J Peasant Stud 37(4): 899-916. doi:10.1080/03066150.2010.512463

Wada Y, Beek L, Bierkens MF (2012) Nonsustainable groundwater sustaining irrigation: a global assessment. Water Resour Res 48(6):W00L06 
Wallis PJ, Ward MB, Pittock J, Hussey K, Bamsey H, Denis A, Kenway SJ, King CW, Mushtaq S, Retamal ML, Spies BR (2014) The water impacts of climate change mitigation measures. Clim Change 125(2):209-220. doi:10.1007/s10584-014-1156-6

Webber Energy Group (n.d.) Texas interactive power stimulator. University of Texas, Austin

Williams J, Pittock J (2012) Unconventional gas production and water resources, Lessons from the United States on better governance - a workshop for Australian Government officials. The Australian National University and United States Studies Centre, Canberra

WWDR (2012) Managing water under uncertainty and risk, Fourth world water development report. UNESCO, Paris

Yang J, Xu M, Zhang X, Hu Q, Sommerfeld M, Chen Y (2011) Life-cycle analysis on biodiesel production from microalgae: water footprint and nutrients balance. Bioresour Technol 102(1): 159-165. doi:10.1016/j.biortech.2010.07.017

Zoomers A (2010) Globalisation and the foreignisation of space: seven processes driving the current global land grab. J Peasant Stud 37(2):429-447. doi:10.1080/03066151003595325 